\title{
PENGARUH MODEL PEMBELAJARAN BERBASIS MASALAH BERBANTUAN ALAT PERAGA TIGA DIMENSI TERHADAP HASIL BELAJAR FISIKA PESERTA DIDIK TAHUN PELAJARAN 2017/2018
}

\author{
Pitriah*, Sutrio, Muhammad Taufik \\ Program Studi Pendidikan Fisika, Universitas Mataram \\ *Email: pitriaharpah488@gmail.com
}

\begin{abstract}
This study aims to determine the effect of problem-based learning model with three dimensional figure toward physics learning outcome of students in grade XI SMAN 1 Gerung. This type of research is quasi experiment with non-equivalent control group design, which sample using purposive sampling technique, so that obtained class XI MIPA 5 as experiment class and class XI MIPA 4 as control class. The instrument used is a multiple choice test of 25 questions that have been tested for validity, reliability, level of difficulty, and different power of problems. The learning data of the two classes is normally distributed and homogeneous. Technique of data analysis using the parametric statistic test formula t-test polled variance with a significant level $5 \%$ and obtained $t_{\text {count }}=$ $3,50, t_{\text {table }}=1,996$, so $t_{\text {count }}>t_{\text {table }}$. Based on the result, it can be concluded that there is the effect of treatment of problem based learning model with three dimensional figure toward physics learning outcome of students.
\end{abstract}

Keywords: Problem-based learning model, three dimensional figure, learning outcome

\section{PENDAHULUAN}

Sains (IPA) didefinisikan sebagai ilmu yang mempelajari tentang sebab akibat peristiwa-peristiwa yang terjadi di alam. IPA juga dapat diartikan sebagai kumpulan pengetahuan dapat berupa fakta, konsep, prinsip, hukum, teori dan model (Hikmawatiet al., 2013). Dapat pula dikatakan bahwa IPA merupakan ilmu yang berkaitan dengan cara mencari tahu tentang alam secara sistematis sehingga IPA bukan hanya penguasaan kumpulan pengetahuan berupa fakata-fakta, konsep, atau prinsip saja, tetapi juga merupakan proses penemuan (Fitriani et al. 2017). Lebih lanjut Trianto (2010) mengatakan bahwa IPA adalah ilmu pengetahuan yang mempelajari gejala-gejala melalui serangkaian proses yang dikenal denganproses ilmiah yang dibangun atas dasar sikap ilmiah dan hasilnya terwujud sebagai produk ilmiah yang tersusun atas tiga komponen terpenting berupa konsep, prinsip, dan teori.

$$
\text { Hermansyah et al. (2015) }
$$

menyatakan bahwa fisika adalah ilmu yang mengkaji interaksi antara energi dan materi yang menjadi dasar dari ilmu pengetahuan alam. Pendapat lain disampaikan oleh Helmi et al. (2017) menyatakan bahwa fisika merupakan salah satu cabang ilmu pengetahuan alam yang terdiri dari konsep, prinsip, teori dan atau hukum terkait dengan gejala-gejala alam yang ada. Lebih lanjut Hikmawati et al. (2013) menjelaskan bahwa fisika merupakan salah satu cabang ilmu IPA (sains) memiliki hakikat yakni fisika sebagai produk ( a body of knowledge), fisika sebagai sikap (a way of thinking), dan cara penyelidikan (a way of investigating).

Jika dicermati dari hakikatnya, pembelajaran fisika diarahkan ke suatu tujuan yaitu agar peserta didik dapat mengembangkan kemampuan intelektualnya, berfikir kritis, logis, dan ilmiah serta mampu memahami konsep, dan memecahkan masalah terutama yang 
yang berkaitan dengan kehidupan seharihari. Hal ini menuntut keaktifan peserta didik selama proses pembelajaran melalui upaya peserta didik untuk menemukan sendiri pemecahan masalah yang mereka hadapi terkait dengan pembelajaran fisika, sehingga akan tercipta pembelajaran yang berpusat pada peserta didik (student centered).

Guru harus memiliki kemampuan dalam menggunakan suatu model dan metode pembelajaran yang efektif guna meningkatkan hasil belajar peserta didik agar optimal. Selain model dan metode pembelajaran, guru juga harus memiliki keterampilan dalam memilih dan menggunakan media pembelajaran agar dapat merangsang peserta didik untuk berpartisipasi secara aktif dalam proses belajar. Hal ini, didukung oleh pendapat dari Arsyad (2013) media pembelajaran adalah segala sesuatu yang dapat digunakan untuk menyampaikan informasi dalam proses belajar mengajar sehingga dapat merangsang perhatian dan minat peserta didik dalam belajar. Penerapan metode dan model serta pemilihan media yang tepat diharapkan dapat menciptakan proses belajar mengajar yang efektif, efisien, dan meningkatkan interaksi peserta didik dengan sumber belajar.

Namun demikian kondisi pembelajaran fisika di berbagai jenjang pendidikan tidaklah demikian. Berdasarkan hasil observasi dan wawancara yang sudah peneliti lakukanpada peserta didik kelas XI MIPA di SMA Negeri 1 Gerung, terdapat beberapa masalah yang ditemukan pada saat proses pembelajaran. Peserta didik terlihat kurang berminat mengikuti pelajaran fisika, peserta didik kebanyakan mengantuk, peserta didik jarang bertanya, tidak mendengarkan penjelasan dari guru. Hal ini disebabkan karena kurangnya interaksi antara peserta didik dan guru yang menyebabkan pembelajaran menjadi satu arah (teacher centered). Masalah lain yang ditemukan yaitu beberapa peserta didik cenderung hanya mendengarkan dan mencatat informasi-informasi yang diberikan oleh guru.

Sementara itu, hasil wawancara dengan salah satu guru fisika SMA Negeri 1 Gerung, diperoleh informasi yang dapat disimpulkan bahwa guru sudah mengupayakan menggunakan variasi model pembelajaran namun kebanyakan menggunakan metode ceramah tanpa melihat kemungkinan metode dan model pembelajaran yang sesuai dengan karakteristik dari peserta didik dan materi yang akan diajarkan, sehingga peserta didik kurang aktif pada saat belajar dan kegiatan pembelajaran masih terpaku pada buku sebagai bahan ajar dan guru. Faktor lain yaitu, pada proses pembelajaran fisika penggunaan media ataupun alat peraga belum digunakan secara optimal, sehingga menyebabkan pembelajaran menjadi monoton dan pasif. Hal ini berdampak pada hasil belajar fisika peserta didik yang rendah, rata-rata di bawah Kriteria Ketuntasan Minimal (KKM). Adapun KKM untuk mata pelajaran Fisika adalah 75.

Berdasarkan

pemaparan

permasalahan tersebut, maka dilakukan upaya memilih suatu model pembelajaran yang lebih aktif, kreatif, dan menyenangkan yang dapat memotivasi peserta didik dalam meningkatkan hasil belajar fisika peserta didik. Salah satu model pembelajaran menurut peneliti yakni dengan menerapkan model pembelajaran berbasis masalah (PBM). Model pembelajaran berbasis masalah ini memfokuskan pada peserta didik dengan mengarahkan peserta didik menjadi pembelajar yang mandiri dan terlibat langsung secara aktif dalam pembelajaran kelompok, sehingga dapat membantu peserta didik untuk mengembangkan berpikir peserta didik dalam mencari pemecahan masalah melalui pencarian data 
sehingga diperoleh solusi untuk suatu masalah dengan rasional dan autentik.

Keberhasilan dalam proses pembelajaran, selain dipengaruhi oleh model dan metode pembelajaran juga dipengaruhi oleh media pembelajaran, sehingga diperlukan suatu media pembelajaran yang dapat membuat peserta didik lebih aktif pada saat belajar karena terlibat secara langsung. Salah satu media pembelajaran yakni dengan menggunakan alat peraga tiga dimensi, sehingga peserta didik dapat memahami materi pelajaran yang masih bersifat abstrak kemudian di konkretkan dengan menggunakan alat peraga, karena dapat dijangkau dengan pikiran yang sederhana dan dapat dilihat, dipandang, dan dirasakan.

Penelitian-penelitian sebelumnya menunjukan pengaruh model pembelajaran berbasis masalah berbantuan alat peraga tiga dimensi dalam pembelajaran. Hasil penelitian Rachmawati et al., (2015) menunjukan model pembelajaran berbasis masalah berbantuan alat peraga tiga dimensi dapat meningkatkan hasil belajar. Hasil penelitian Wulandari et al., (2013) menunjukkan perbedaan hasil belajar yang lebih tinggi menggunakan model pembelajaran berbasis masalah berbantuan alat peraga tiga dimensi dibandingkan model demonstrasi. Peneliti berharap dengan menggunakan model pembelajaran berbasis masalah berbantuan alat peraga tiga dimensi mampu meningkatkan hasil belajar fisika peserta didik.

\section{METODE PENELITIAN}

Jenis penelitian yang digunakan dalam penelitian ini adalah quasi eksperimen dengan desain Non-eqivalent Control Group Design. Sebelum diberi perlakuan kedua kelompok sampel diberikan tes awal untuk mengetahui keadaan awal. Selanjutnya kelas eksperimen diberikan perlakuan dengan model pembelajaran berbasis masalah berbantuan alat peraga tiga dimensi dan kelas kontrol diberi perlakuan berupa model pembelajaran konvensional. Pada akhir perlakuan, kedua kelas diberi pengukuran yang sama Populasi dalam penelitian ini adalah seluruh peserta didik kelas XI MIPA di SMAN 1 Gerung tahun ajaran 2017/2018 yang berjumlah 7 kelas. Sedangkan sampel adalah bagian dari populasi. Sampel yang digunakan dipilih dengan menggunakan teknik purposive sampling. Dalam penelitian ini, yang diukur hasil belajar pada ranah kognitif, afektif, dan psikomotor.

Hasil belajar pada ranah kognitif digunakan tes pilihan ganda sebanyak 25 soal, sedangkan penilaian pada ranah afektif dan psikomotor menggunakan lembar observasi. Sebelumnya tes pilihan ganda di uji validitasnya sehingga diperoleh 25 soal yang valid. Uji $F$ digunakan untuk mengetahui homogenitas data dan uji normalitas untuk mengetahui apakah data terdistribusi normal atau tidak. Setelah itu, untuk mengetahui peningkatan nilai kedua tes sebelum dan sesudah diberi perlakuan digunakan uji t polled varians.

\section{HASIL DAN PEMBAHASAN}

Berdasarkan ranah yang dinilai yaitu kognitif, afektif, dan psikomotor. Data penelitian hasil belajar fisika peserta didik terdiri dari hasil tes awal dan tes akhir berupa data hasil belajar kognitif dengan cara uji normalitas, uji homogenitas, dan uji hipotesis dan data hasil nilai afektif serta psikomotor. Tes awal dilakukan untuk mengetahui homogenitas serta normalitas sampel. Adapun hasil tes awal dapat dilihat pada tabel 1. Pada hasil tes awal, diperoleh nilai tertinggi dan terendah pada kelas eksperimen maupun kontrol sama yaitu 52 dan 12. Nilai rata-rata yang diperoleh pada kelas eksperimen adalah 27,16 dan nilai ratarata pada kelas kontrol adalah 27,57.

Tes akhir bertujuan untuk mengetahui kemampuan akhir peserta didik 
kelas eksperimen maupun kelas kontrol. Data kemampuan akhir yang diperoleh pada penelitian ini adalah data setelah diberikan perlakuan. Tes akhir diberikan untuk mengetahui homogenitas, normalitas dan hipotesis penelitian. Adapun hasil tes akhir kelas eksperimen maupun kelas kontrol dapat dilihatpada Tabel 1. Pada hasil tes akhir, nilai terendah pada kelas eksperimen dan kelas kontrol berturut-turut 64 dan 48, untuk nilai tertinggi dikedua kelas baik kelas eksperimen maupun kelas kontrol berturutturut 92 dan 88, sedangkan untuk nilai ratarata kelas ekperimen 77,16 dan rata-rata nilai kelas kontrol 70,27. Hasil tes mengalami peningkatan yang ditunjukan oleh selisih nilai rata-rata kedua kelas tersebut adalah 6,89 .

Tabel 1. Hasil Belajar Kelas Eksperimen dan Kelas Kontrol

\begin{tabular}{cccccc}
\hline Kelas & $\begin{array}{c}\text { Jumlah } \\
\text { Peserta Didik }\end{array}$ & Kemampuan & $\begin{array}{c}\text { Nilai } \\
\text { Tertinggi }\end{array}$ & $\begin{array}{c}\text { Nilai } \\
\text { Terendah }\end{array}$ & Rata-rata \\
\hline Eksperimen & 38 & Awal & 52 & 12 & 27,16 \\
Kontrol & 37 & & 52 & 12 & 27,57 \\
Eksperimen & 38 & Akhir & 92 & 64 & 77,16 \\
Kontrol & 37 & & 88 & 48 & 70,27 \\
\hline
\end{tabular}

Pengujian data hasil belajar untuk kelas eksperimen dan kelas kontrol tes awal dan tes akhir diawali dengan uji homogenitas kedua data, yang dilanjutkan dengan uji normalitas, dan terakhir uji hipotesis menggunakan uji-t polled varians. Dari uji homogenitas data untuk tes awal yang telah dilakukan didapat hasil nilai $\mathrm{F}_{\text {hitung }}$ sebesar 1,25 sedangkan nilai $F_{\text {tabel }} 1,72$ dengan taraf signifikan 0,05 , sehingga dapat dikatakan $F_{\text {hitung }}<F_{\text {tabel}}$, maka varians-variansnya homogen. Artinya kedua data kelas homogen dan dapat dikatakan kedua kelas memiliki kemampuan awal yang sama. Selanjutnya dilakukan uji normalitas data tes awal dan tes akhir pada masing-masing kelas. Berdasarkan perhitungan yang telah dlakukan didapatkan hasil bahwa data terdistribusi normal pada tes awal dan tes akhir untuk kelas eksperimen dan kelas kontrol. Untuk tes awal didapatkan nilai $\chi_{\text {hitung sebesar 5,2631 untuk kelas }}^{2}$ eksperimen dan 7,8882 untuk kelas kontrol. Nilai $\chi_{\text {tabel }}^{2}$ dengan taraf signifikan 0,05 untuk kelas eksperimen maupun kelas kontrol 11,070. Hasil dari kedua data tersebut menunjukan bahwa $\chi_{\text {hitung }}^{2}<\chi_{\text {tabel, }}^{2}$ sehingga dapat dikatakan bahwa data tes awal kedua kelas terdistribusi normal.

Data untuk tes akhir setelah dilakukan uji homogenitas diperoleh nilai $F_{\text {hitung }}$ sebesar 1,40 sedangkan nilai $F_{\text {tabel }} 1,72$ dengan taraf signifikan 0,05, sehingga dapat dikatan bahwa $F_{\text {hitung }}<F_{\text {tabel, }}$ maka variansvariansnya homogen. Artinya kedua data kelas homogen. Selanjutnya dilakukan uji normalitas data tes akhir diperoleh nilai $\chi_{\text {hitung }}^{2}$ untuk kelas eksperimen sebesar 2,5880 dan untuk kelas kontrol sebesar 4,2785 . Nilai $\chi_{\text {tabel }}^{2}$ dengan taraf signifikan 0,05 untuk kedua kelas adalah 11,070 sehingga data tes akhir kedua kelas terdistribusi normal.

Berdasarkan hasil uji hipotesis dengan menggunakan uji-t polled varians, kedua kelas samel menunjukan bahwa nilai $t_{\text {hitung }}=3,50$ lebih besar dari $t_{\text {tabel }}=1,996$ pada taraf signifikan 0,05 . Hal ini berarti $\mathrm{H}_{0}$ ditolak, sehingga dapat disimpulkan bahwa penggunaan model pembelajaran berbasis masalah berbantuan alat peraga tiga dimensi berpengaruh dalam meningkatkan hasil belajar secara signifikan. Hasil penelitian ini sejalan dengan penelitian sebelumnya, Rachmawati et al. (2015) mengatakan bahwa model pembelajaran berbasis 
masalah berbantuan alat peraga tiga dimensi dapat meningkatkan hasil belajar secara signifikan. Penelitian ini juga didukung oleh penelitian sebelumnya, Wulandari et al., (2013) mengatakan bahwa terdapat perbedaan hasil belajar yang signifikan antara peserta didik yang diajar menggunakan model pembelajaran berbasis masalah dengan peserta didik yang diajar menggunakan demonstrasi. Penelitian sebelumnya oleh Nurqomariah et al. (2015) menyatakan bahwa penerapan model pembelajaran berbasis masalah (problem based learning) dapat meningkatkan hasil belajar peserta didik. Penelitian sebelumnya oleh Hikmawati et al. (2018) yang mengatakan bahwa dengan penerapan media tiga dimensi pada proses pembelajaran memberikan pengalaman langsung pada peserta didik sehingga materi yang disampaikan lebih menarik dan terdapat berbagai hal ilmu pengetahuan yang dapat diambil berhubungan dengan media pembelajaran.

Selain itu, penerapan model pembelajaran berbasis masalah berbantuan alat peraga tiga dimensi juga dapat mendorong peserta didik lebih aktif dalam belajar serta dapat mendorong kolaboratif dalam belajar.Hasil penelitian ini juga diperkuat dengan hasil penelitian sebelumnya, Jiniarti et al., (2017) berpendapat bahwa implementasi model pembelajaran berbasis masalah berbantuan alat peraga dapat memberi manfaat positf bagi peserta didik dan guru, bahwa model pembelajaran berbasis masalah mendorong peserta didik untuk belajar secara aktif, mendorong terciptanya kolaboratif dan mampu meningkatkan kualitas pendidikan.

Pembelajaran berbasis masalah dapat pula menubuhkembangkan kemampuan kreativitas peserta didik, baik secara induvidual maupun secara kelompok karena hampir disetiap langkah kegiatan menuntut keaktifan peserta didik serta dengan menerapkan pembelajaran berbasis masalah yang diterapkan dapat meningkatkan kemampuan pemecahan masalah. Hal ini sejalan dengan pendapat Riyanto (2009) mengatakan bahwa model pembelajaran berbasis masalah dikembangkan untuk mengembangkan kemampuan peserta didik memecahkan masalah. Peneltian ini juga diperkuat oleh Gunada et al. (2015) yang menyatakan bahwa pemecahan masalah yang dilakukan pada model pembelajaran berbasis masalah dapat mengembangkan kemampuan berfikir tingkat tinggi dan berfikir kritis yang pada akhirnya mengarahkan peserta didik untuk dapat mencapai hasil belajar yang lebih baik.

Penilaian hasil belajar pada ranah afektif untuk kelas eksperimen dan kelas kontrol yang diamati secara induvidu oleh observer untuk setiap peserta didik.Aspek yang dinilai adalah kedisiplinan, keaktifan, kerja sama dan tanggung jawab serta menghargai orang lain selama proses pembelajaran berlangsung. Adapun rekapitulasi data afektif yang diperoleh dari hasil observasi untuk kelas eksperimen maupun kelas kontrol dapat dilihat pada Gambar 1. Pada hasil belajar afektif, diperoleh nilai setiap pertemuan mengalami peningkatan baik pada kelas eksperimen maupun kelas kontrol. Jika dibandingkan nilai rata-rata kedua kelas, kelas eksperimen lebih baik dibandingkan dengan kelas kontrol. Hal ini disebabkan, penggunaan model pembelajaran berbasis masalah berbantuan alat peraga tiga dimensi menjadikan peserta didik sebagai produsen pengetahuannya berdasarkan penemuan sendiri bersama anggota kelompoknya. Proses pembelajaran tersebut secara tidak langsung dapat membantu peserta didik mengembangkan sikap berupa komunikasi, penalaran, dan berfikir kritis ketika memecahkan masalah bersama kelompoknya. Hasil penelitian ini didukung oleh penelitian Af'idah et al., (2014) 
menyatakan bahwa penerapan model mengembangkan keterampilan sikap dan pembelajaran berbasis masalah dapat kerja sama dalam berbagai situasi.

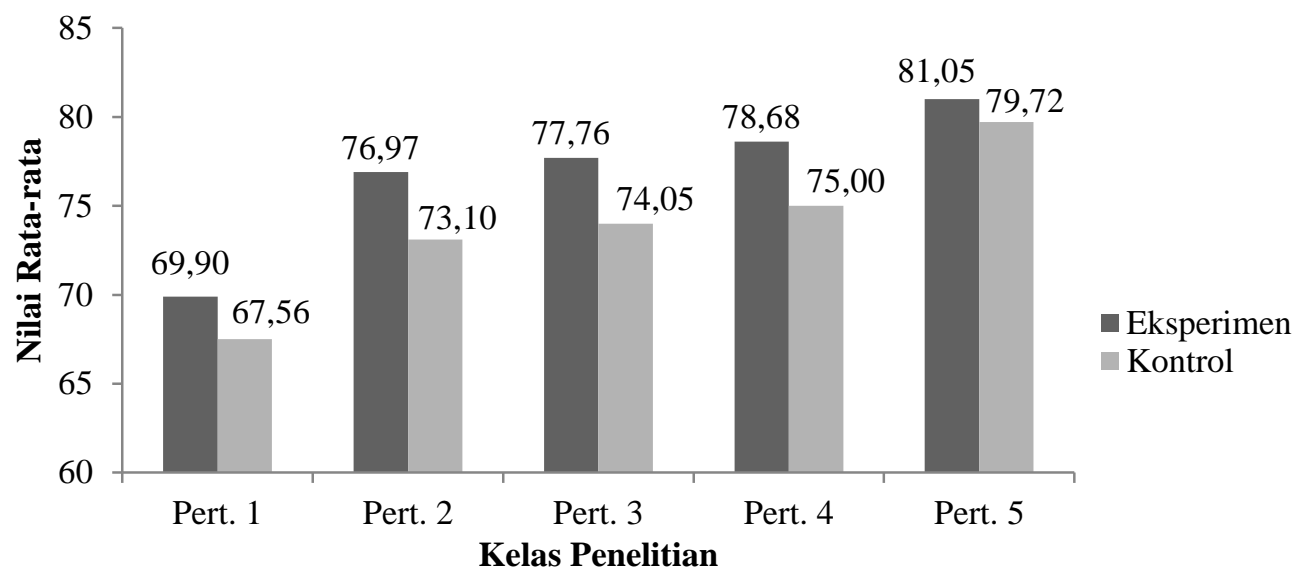

Gambar 1. Rekapitulasi Nilai Hasil Belajar Afektif Kelas Eksperimen dan Kelas Kontrol

Hasil belajar pada ranah psikomotor lebih menekankan pada pemberian pengalaman kepada peserta didik untuk terampil mengerjakan sesuatu dengan menggunakan keadaan yang dimiliki. Penilaian hasil belajar pada ranah psikomotor untuk kelas eksperimen dan kelas kontrol yang diamati secara induvidu oleh observer untuk setiap peserta didik. Aspek yang dinilai selain memiliki keterampilan dalam menggunakan alatpada saat melakukan percobaan, peserta didik juga harus memiliki keterampilan dalam mempresentasikan atau mengkomunikasikan hasil percobaan yang didapat. Selain itu, isi yang dipresentasikan harus jelas. Adapun rekapitulasi hasil belajar psikomotor yang diperoleh dari hasil observasi untuk kelas eksperimen dan kelas kontrol disajikan dalam Gambar 2.

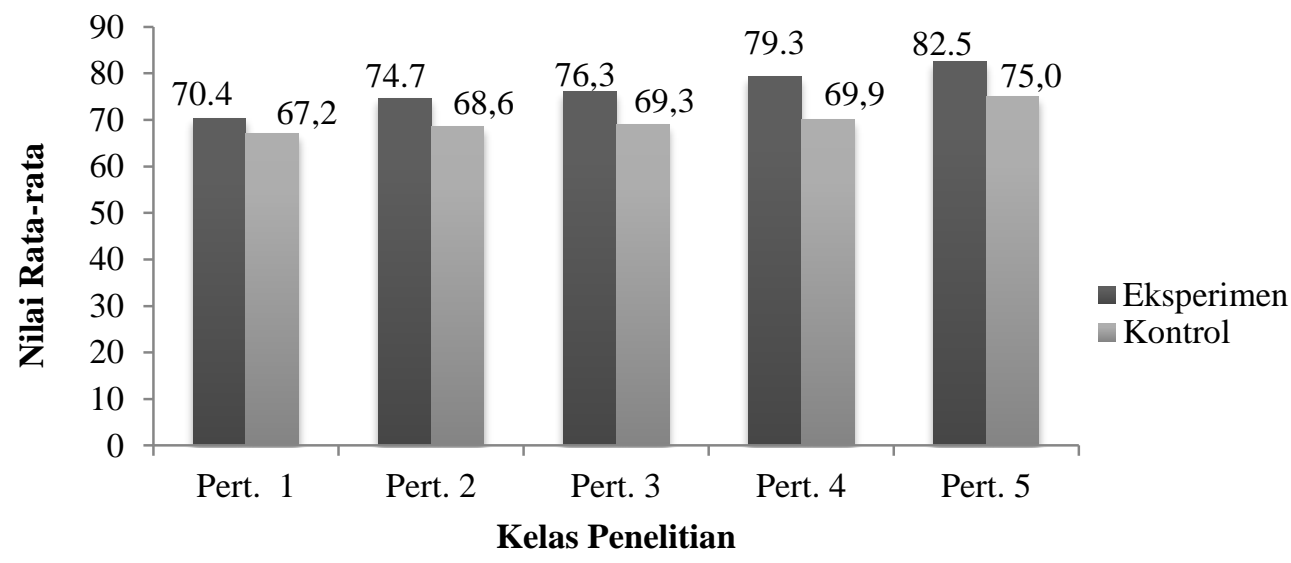

Gambar 2.Rekapitulasi Nilai Hasil Belajar Psikomotor Kelas eksperimen dan KelasKontrol

Berdasarkan analisis pada Gambar 2, terlihat bahwa setiap pertemuan mengalami peningkatan baik pada kelas eksperimen maupun kelas kontrol. Jika dibandingkan nilai rata-rata kedua kelas, kelas eksperimen lebih baik dibandingkan dengan kelas kontrol. Hal ini disebabkan, penggunaan model pembelajaran berbasis masalah berbantuan alat peraga tiga dimensi memberikan kesempatan kepada peserta didik untuk mengembangkan kemampuan psikomotornya yang berkaitan dengan keterampilan berkomunikasi berupa presentasi dan menanya atau menanggapi. 
Hasil penelitian ini didukung oleh penelitian Af'idah et al., (2013) mengatakan bahwa model pembelajaran berbasis masalah dapat digunakan untuk mengembangkan keterampilan-keterampilan psikomotor.

\section{KESIMPULAN DAN SARAN}

Berdasarkan hasil penelitian dan pembahasan, maka dapat ditarik kesimpulan bahwa terdapat pengaruh model pembelajaran berbasis masalah berbantuan alat peraga tiga dimensi terhadap hasilbelajar fisika peserta didik. Adapun saran yang dapat diberikan bagi guru fisika model pembelajaran berbasis masalah berbantuan alat peraga tiga dimensi dapat dijadikan alternatif dalam mengajar fisika. Namun, dalam penerapannya perlu memperhatikan alokasi waktu sebaik mungkin sehingga pembelajaran dapat berlangsung secara optimal. Sedangkan untuk peneliti selanjutnya diharapkan lebih cermat dalam memadukan model pembelajaran berbasis masalah dengan bantuan media lainnya sesuai dengan materi yang diajarkan agar hasil yang dicapai sesuai dengan tujuan yang diharapkan.

\section{REFERENSI.}

Af'idah, A, R., Erman.,\& Budiyanto, M. 2013. Penerapan Model Pembelajaran Berdasarkan Masalah Pada Pembelajaran IPA Terpadu Tema Korosi Besi Untuk Siswa Kelas VII SMP Negeri 1 Bungah Gresik. Jurnal Pendidikan Sains, 1(1), 66-70.

Arsyad, A. 2013. Media Pembelajaran Edisi Revisi. Depok: Rajagrafindo Persada.

Fitriani, N., Gunawan, G., \& Sutrio, S. 2017. Berfikir Kreatif dalam Fisika dengan Pembelajaran Conceptual Understanding Procedures (CUPs) Berbantuan LKPD. Journal Pendidikan Fisika dan Teknologi, 3(1), 24-33.
Gunada, I.W., \& Hikmawati. 2013. Kajian Fisika SMA. Mataram: FKIP Press.

Gunada, I. W., Sahidu, H., \& Sutrio, S. 2015. Pengembangan Perangkat

Pembelajaran Fisika Berbasis Masalah untuk Meningkatkan Hasil Belajar dan Sikap Ilmiah Mahasiswa. Jurnal Pendidikan Fisika dan Teknologi, 1(1).

Helmi, F., Rokhmat, J. 2017. Pengaruh Pendekatan Berpikir Kausalitik Berscaffolding Tipe $2 b$ Termodifikasi Berbantuan Lks Terhadap Kemampuan Pemecahan Masalah Fluida Dinamis Siswa. Jurnal Pendidikan Fisika dan Teknologi, 3(1), 68-75.

Hermansyah, H., Gunawan, G., \&Herayanti, L. 2015. Pengaruh Penggunaan Laboratorium Virtual Terhadap Penguasaan Konsep dan Kemampuan Berfikir Kreatif Siswa pada materi getaran dan gelombang. Jurnal Pendidikan Fisika dan Teknologi, 1(2), 97-102.

Hikmawati, H., Rokhmat, J., \& Sutrio, S. 2018. Penyuluhan Pembuatan Media Tiga Dimensi dan Penerapannya Melalui Model Siklus Belajar 5E Pada Guru-Guru di MGMP Fisika SeLombok Barat. Jurnal Pendidikan dan pengabdian Masyarakat, 1(1).

Jiniarti, B. E., Sahidu, H., \& Verawati, N. N. S. P. 2017. Implementasi Model Problem Based Learning Berbntuan Alat Perga Untuk Meningkatkan Aktivitas Dan Hasil Belajar Fisika Siswa Kelas VIII SMPN 22 Mataram Tahun Pelajaran 2014/2015. Jurnal Pendidikan Fisika dan Teknologi, 1(3), 185-192.

Nurqomariah, N., Gunawan, G.,\& Sutrio, S. 2015. Pengaruh Model Problem Based Learning dengan Metode Eksperimen Terhadap Hasil Belajar IPA Fisika Siswa Kelas VII SMP Negeri 19 Mataram Tahun Pelajaran 2014/2015. Jurnal Pendidikan Fisika dan Teknologi, 1(3), 173-179. 
Rachmawati, D., Sudarmin.,\& Dewi, N. R. 2015. Efektivitas Problem Based Learning(PBL) Pada Tema Bunyi dan Pendengaran Berbantuan Alat Peraga Tiga Dimensi Terhadap Kemampuan Berpikir Kritis Siswa SMP. Unnes Science Education Journal, 4(3).

Riyanto, Y. 2009. Paradigma Baru Pembelajaran. Surabaya: Prenada Media Group.

Trianto. 2010. Model Pembelajaran Terpadu Konsep, Strategi, dan Implementasinyadalam Kurikulum Tingkat Satuan Pendidikan (KTSP). Jakarta: Bumi Aksara.

Wulandari, B. \& Surjono, H, D. 2013. Pengaruh Problem Based Learning Terhadap Hasil Belajar Ditinjau Dari Motivasi Belajar PLC DI SMK. Jurnal Pendidikan Vokasi, 3(2), 178191. 